\section{Os eventos de letramento de discentes do projeto Universidade Para Todos: uma análise qualitativa}

Literacy events of students from Universidade Para Todos project: a qualitative analysis

Fernando Álisson Santos SAMPAIO (UFBA) fernando.ssampaio@yahoo.com.br

Tiago Alves NUNES (UFBA) tiagopark@gmail.com

Recebido em: 21 de jun. de 2020. Aceito em: 07 de set. de 2020.

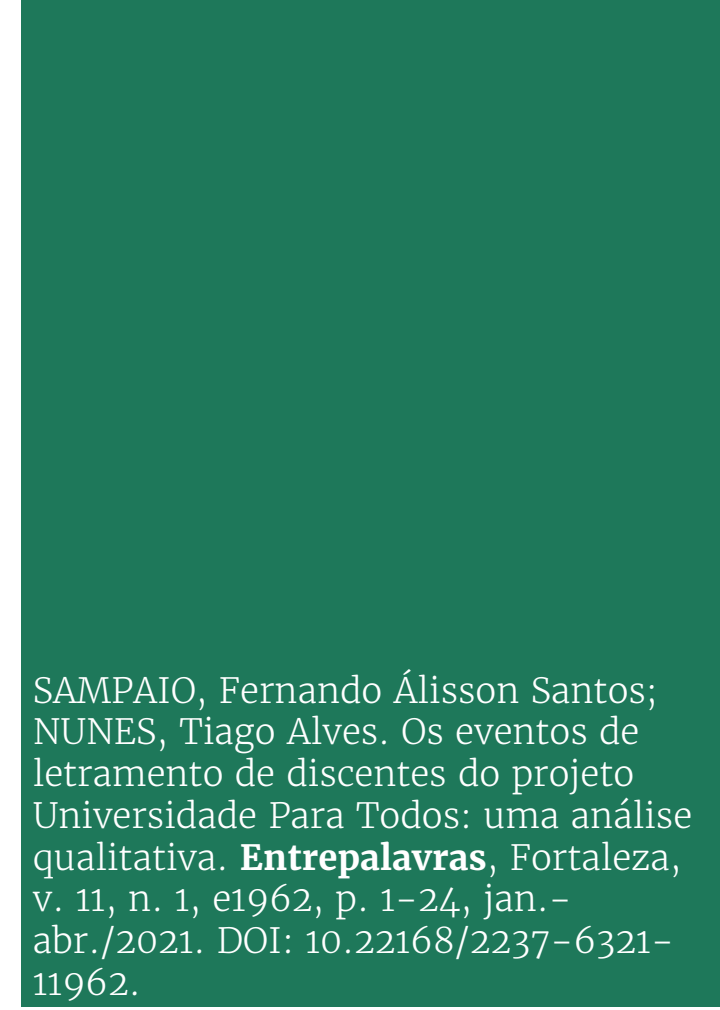

Resumo: O Projeto Universidade para Todos (UPT) foi uma iniciativa da Secretaria da Educação da Bahia em parceria com universidades estaduais (UNEB, UEFS, UESB, UESC), cujo objetivo é o fortalecimento de uma política voltada à inserção de estudantes da rede pública estadual no ensino superior. Nesse contexto, este estudo objetiva analisar os eventos de letramento nos quais estudantes do projeto UPT estão imersos, no intento de saber e compreender quais textos são os mais acessíveis e que relações eles mantêm com esses eventos comunicativos. De caráter diagnóstico, o estudo possui como instrumento para geração do corpus o questionário misto, que foi aplicado a 31 discentes, oriundos do referido projeto, em duas escolas públicas da cidade de Salvador (BA). Ancoramo-nos, teoricamente, nos conceitos de letramento (ROJO, 2009; KLEIMAN, 2014; BAPTISTA, 2010) e eventos de letramento (STREET; CASTANHEIRA, 2014; STREET, 2000). Após a análise dos dados, notou-se que a natureza diversa do alunado faz com que o acesso aos eventos de letramentos também seja variado. Ademais, a relação que se mantém com os textos, igualmente, depende do acesso e diversidade de eventos comunicativos, influenciando, assim, na aprendizagem de língua portuguesa com vista ao objetivo que o UPT se propõe.

Palavras-chave: Letramento. Eventos de letramento. Universidade para Todos. 
V. $11(1)$

$1-24$

jan-abr

2021

Abstract: The University for everybody's Project (Universidade para Todos Project - UPT) was an initiative of the Bahia Department of Education in partnership with state universities (UNEB, UEFS, UESB, UESC), which objective was to strengthen a policy aimed at inserting students from state public school into higher education. In this context, this study aims to analyze the literacy events in which UPT students are immersed, in order to know and understand which text genres are the most accessible and what relationships they have with these communicative events. The study has a diagnostic character and has as instrument for corpus generation the mixed questionnaire, which was applied to 31 students from this project in two public schools in the city of Salvador (BA). We are theoretically anchored in the concepts of literacy and literacy events (ROJO, 2009; KLEIMAN, 2014; STREET; CASTANHEIRA, 2014; STREET, 2000; BAPTISTA, 2010). After analyzing the data, it was noted that the diverse nature of the students makes access to literacy events also varied. Moreover, the relationship that remains with the texts also depends on the access and diversity of communicative events, thus influencing the learning of the Portuguese language with a view to the purpose that the UPT proposes.

Keywords: Literacy. Literacy events. University for everybody.

\section{Introdução}

Muito se discute, na atualidade, sobre as possíveis causas do fracasso escolar no que tange à promoção de uma educação libertadora, na qual o aluno possa se perceber como sujeito participante do seu processo de aprendizagem. Tais queixas têm se tornado frequentes em todos os segmentos (da educação básica ao ensino superior) e em todas as disciplinas. Contudo, as discussões acerca das projeções para o ensino de língua portuguesa, em especial, nos últimos anos, têm nos chamado mais atenção, principalmente, no que tange ao trabalho com a leitura e com a escrita.

Sob esse prisma, acreditamos que o problema do sistema educacional seja de ordem estrutural, no qual o professor, por si só, não pode (nem deve) assumir a total responsabilidade por esse cenário. Isso porque o mesmo constitui-se apenas como uma peça integrante dessa engrenagem que movimenta o nosso sistema de educação e, sobretudo, desempenha um papel que, em geral, ultrapassa os aspectos ensejados na sua formação.

Assim, embora o problema no campo da leitura e da escrita esteja imbricado na falta de estrutura nas escolas, de professores capacitados, na preparação teórica e metodológica, na falta de mobilização social e de investimentos, por via do Estado, para uma educação de qualidade, pensamos que um ponto de partida, para minimizar esse entrave, seja a tomada de ciência das práticas e eventos de letramento do nosso alunado. 
Em outras palavras, conhecer os textos (escritos e orais) que permeiam o universo dos nossos estudantes configura-se como uma alternativa para tornar as aulas de língua materna mais efetivas. Nesse sentido, assim como Freire (1989, p.13), acreditamos que

[...] a leitura do mundo precede sempre a leitura da palavra e a leitura desta implica a continuidade da leitura daquele. Na proposta a que me referi acima, este movimento do mundo à palavra e da palavra ao mundo está sempre presente. Movimento em que a palavra dita flui do mundo mesmo através da leitura que dele fazemos. De alguma maneira, porém, podemos ir mais longe e dizer que a leitura da palavra não é apenas precedida pela leitura do mundo, mas por uma certa forma de 'escrevêlo' ou de 'reescrevê-lo', quer dizer, de transformá-lo através de nossa prática consciente.

O que notamos, assim, é que a escola tem fomentado uma prática de ensino contrária à que foi exposta por Freire, desprezando os conhecimentos trazidos pelos alunos e não reconhecendo os eventos de letramento dos quais o estudante participa, principalmente, se oriundo das camadas populares. A consequência disso tem sido uma educação pautada apenas nas práticas de escrita valorizadas, porém distanciadas desse alunado, o qual, ao chegar à escola, depara-se com uma língua completamente diferente da sua, tida como inacessível, e que, agora, passa a ser considerada como a "língua do outro".

De forma análoga, muitos estudantes das camadas populares acabam por apresentar uma trajetória escolar truncada, marcada pela exclusão social e pelo não desenvolvimento de habilidades e competências atinentes à prática do ato de ler. Tal fato dificulta, em muitos casos, o acesso a níveis mais complexos de estudo, como, por exemplo, o nível universitário.

Nesse sentido, o presente trabalho tem como objetivo analisar os eventos de letramento nos quais estudantes do projeto UPT ${ }^{1}$ estão imersos, no intento de saber e compreender quais textos eles têm mais contato e que relações mantêm com esses eventos comunicativos. Para tanto, como instrumento para a geração de dados, aplicamos um questionário misto, baseado na investigação de Furtado (2011), para 31 estudantes do UPT, em duas escolas que atendem ao projeto, ambas localizadas na periferia de Salvador.

\footnotetext{
${ }^{1}$ O Projeto Universidade para Todos (UPT) é uma iniciativa da Secretaria da Educação da Bahia em parceria com universidades estaduais (UNEB, UEFS, UESB, UESC), cujo foco é o fortalecimento de uma política voltada à inserção de estudantes da rede pública estadual no ensino superior. $\mathrm{O}$ referido projeto tem como objetivo diminuir as condições de desigualdades presentes no acesso à educação universitária, entre escolas particulares e públicas, congregando aulas preparatórias para alunos das escolas do Estado em vista ao ingresso em universidades.
} 
V. 11 (1) $1-24$ jan-abr 2021

De caráter diagnóstico, este estudo enseja apresentar e discutir os eventos de letramento dos quais os discentes participam, pois acreditamos que esse reconhecimento facilitará a criação de uma prática de ensino de língua materna mais efetivo, principalmente, para aqueles que apresentam eventos e práticas de letramento mais distantes daquelas valorizadas socialmente. Cremos, também, que essa medida possa se adequar a outros contextos de ensino, de modo a contribuir para o enfrentamento de dois grandes problemas que assolam a educação voltada para as classes populares, a saber: evitar a exclusão escolar e tornar a experiência na escola significativa em termos de letramento e de acesso ao conhecimento, ao poder e à informação, o que, em outras palavras, implica combater uma educação linguística elitista e excludente.

\section{O cursinho pré-vestibular Universidade para Todos (UPT) como uma política pública de acesso ao ensino superior}

$\mathrm{O}$ acesso às universidades públicas tem se tornado um grande dilema para os estudiosos do campo educacional e das ciências sociais, tendo, assim, gerado controvérsias e embates acerca das suas políticas de acesso. Embora, nos últimos 20 anos, o acesso ao ensino superior tenha sido uma das prioridades do Governo Federal, o que se verifica, ainda, é um sistema de processos seletivos excludentes e elitistas, em especial, no ingresso às instituições públicas, que apresentam um nível de acirramento mais estreito. É nesse entremeio que as mazelas sociais se tornam evidentes, bem como os processos de exclusão. Isso porque, em geral, tal espaço ainda é ocupado, predominantemente, por alunos oriundos da rede particular.

Segundo o Jornal Extraclasse (2018), a partir de pesquisa realizada pelo IBGE (Instituto Brasileiro de Geografia e Estatística), o percentual de alunos ingressantes no ensino superior público ainda é desigual no que tange ao perfil desse estudante. A pesquisa mostrou que a percentagem dos que ingressam no ensino superior, após completarem o ensino médio no sistema público, é 36\%, ante 79,2\% dos egressos da rede privada. Ademais, a maximização do número de estudantes que estão concluindo o ensino médio e, consequentemente, o aumento na exigência de especialização e da competitividade têm influenciado esses índices. 
É sabido que a qualidade do ensino encontra-se atrelada às condições estruturais, administrativas e pedagógicas do serviço prestado. Nesse sentido, a educação básica pública, em geral, situase numa posição de desvantagem em relação ao setor privado. Vemos, infelizmente, inúmeras críticas tecidas às deficiências na infraestrutura, no material pedagógico, na segurança precária, na desmotivação docente e discente e, sobretudo, na adoção de práticas pedagógicas obsoletas, as quais não se alinham às novas perspectivas de uso das novas tecnologias de ensino, demandadas por uma sociedade altamente industrializada e informatizada. Todos esses entraves apontam para a não equalização das desigualdades entre discentes de escola pública e de escola privada, potencializando, assim, um patamar de competitividade sem condições de igualdade.

De acordo com Ortega (2004), há uma diferenciação de perspectivas entre as formações oferecidas ao setor público e privado. Por um lado, no setor privado, o que se percebe é uma preocupação com uma formação na qual o alunado possa galgar níveis mais complexos de estudo, em especial, rumo ao ensino federal/estadual superior. Por outro lado, o setor público, muitas vezes, não tem apresentado uma preocupação específica nesse sentido; e, quando há, tais esforços estão focados, sobretudo, no último ano do ensino médio. Logo,

[...] podemos perceber que enquanto a escola particular de elite tenta preparar seu aluno para o ingresso numa boa universidade pública, a escola pública não apresenta nenhuma orientação específica neste sentido, colaborando, muito provavelmente sem saber, para que esses alunos não cheguem mesmo a tentar o ingresso no ensino superior. Consideramos que isto pode fazer com que os alunos da escola pública de ensino médio se sintam cada vez mais desmotivados, inseguros e despreparados para viver na sociedade contemporânea, que além de exigir um nível maior de escolaridade, apresenta um contexto preocupante, principalmente para quem não tem uma boa formação geral (ORTEGA, 2004, p.154).

Ao se considerar que o dever da garantia plena da cidadania ocorre quando se tem igualdade de acesso à educação em todos os âmbitos, torna-se fundamental a equalização das disparidades de acesso ao ensino universitário no Brasil. O cenário descrito por Ortega (2004), apesar da data de publicação da obra, descortina o alto grau de elitismo da universidade à época e ainda hoje, a qual, muitas vezes, propicia o seu distanciamento de questões sociais relevantes e emergentes. Com efeito, grupos que foram/são tradicionalmente considerados como 
V. $11(1)$

$1-24$

jan-abr

2021

"minorias", tais como negros, gays, transexuais, mulheres, indígenas, pessoas com deficiência física e alunos de escolas públicas, acabam sendo sub-representados nesse espaço de produção do saber e, sobretudo, de disseminação de inovações para a sociedade.

Por conta disso, e a partir das pressões dos movimentos sociais, emergiram ações como políticas públicas educacionais e sistemas de cotas para tentarem dirimir essa falta de representatividade no intento de tornar a universidade um espaço de produção científico-cultural diversificado e inclusivo.

Nos últimos anos, a universidade pública tem se configurado, portanto, como um espaço múltiplo, singular e, sobretudo, promotor de políticas públicas de acesso à educação em larga escala. Sob esse prisma, visou estabelecer a igualdade de direitos e oportunidades com vista à redução das disparidades socioeconômicas do nosso país. Nesse sentido, os primeiros empreendimentos encaravam tal temática, segundo Santos (2011, p.7),

[...] como ações reparadoras e consideram o acesso por meio de cotas (percentagem) das vagas, aos cursos, destinadas exclusivamente a candidatos de baixa renda, egressos de escolas públicas, de origem negra ou o oferecimento de bônus (acréscimo) na pontuação em seus processos vestibulares.

Essas instituições de ensino estavam exercendo, assim, em certa medida, a possibilidade de desempenhar a sua autonomia acerca dos processos de acesso, via políticas públicas diferenciadas ao espaço universitário. Além disso, a criação de uma política pública aponta para a formação de uma sociedade mais democrática, na qual as condições de equidade de oportunidades sejam tidas como prioridade. É necessário ressaltar, também, que, embora o seu desenvolvimento ocorra por meio do setor público, há a imprescindibilidade da participação dos diversos grupos sociais, em especial, daqueles minoritarizados politicamente.

Torna-se, assim, um passo em prol do bem-estar geral e do direcionamento de recursos e de bens para parcelas da população que, até então, tinham sido privadas desse direito, o qual está previsto em lei, segundo a Constituição Federal, prevendo que,

Art. 205. A educação, direito de todos e dever do Estado e da família, será promovida e incentivada com a colaboração da sociedade, visando ao pleno desenvolvimento da pessoa, seu preparo para o exercício da cidadania e sua qualificação para o trabalho (BRASIL, 1988, s/p). 
Essa dimensão precisa ser alcançada para que o país seja mais justo e igualitário. Por conta disso, a criação de políticas públicas educacionais aponta para esse caminho, ligando população, universidade e conhecimento, o que faz com que os diversos recursos públicos sejam utilizados de forma efetiva e para todos. Uma boa política pública é aquela capaz de alcançar as populações que foram cerceadas do direito de saber.

É nesse cenário que emerge o Pré-vestibular Universidade Para Todos (UPT), como política pública educacional, propondo, na região Nordeste, a democratização e o direito do acesso ao espaço universitário. Esse Projeto é uma parceria das Universidades Públicas do Estado da Bahia (UEFS, UESC, UESB e UNEB) e da Secretaria de Educação da Bahia (SEC-BA), com ações de fortalecimento da política de acesso à educação superior, desde 2004.

Criado pelo governo estadual, por meio do decreto $\mathrm{n}^{0} 9.419$ de 23 de julho de 2004, o projeto UPT tem como público-alvo estudantes concluintes e egressos do ensino médio da rede pública, atuando em diversos territórios da Bahia. Em 2018, por exemplo, o pré-vestibular atendeu cerca de 18.000 estudantes.

No que tange à sua operacionalização, o cursinho perfaz uma carga horária de 20 horas semanais, na modalidade presencial, podendo ocorrer nos turnos matutino, vespertino e noturno. Conta com aulas de Língua Portuguesa, Redação, Matemática, Física, Química, Biologia, Literatura, História, Geografia e Língua Estrangeira (Inglês ou Espanhol), além de atividades complementares, tais como: simulados, capacitações e testes vocacionais aos cursistas que tiverem interesse. Além disso, há o oferecimento de material didático gratuito e a concessão da isenção da taxa nos vestibulares (apenas para os alunos que tiverem $75 \%$ de presença no curso) (WANDERLEY, 2017).

Quanto à sua zona de abrangência, o projeto atende várias regiões periféricas da Bahia, além de espaços onde a universidade, no geral, não alcança, tais como: quilombos, terreiros, comunidades indígenas, centros LGBT e ilhas. Daí uma das grandes façanhas dessa política de desenvolvimento educacional de reparação e de ação afirmativa, a qual, inspirada no que apregoa o artigo 205 da Constituição, destina aos grupos menos abastados a oportunidade de competirem no vestibular em patamares menos desiguais.

Verifica-se, assim, que o UPT está imbricado numa proposta de ação afirmativa e reparativa, posto que almeja instrumentalizar grupos 
V. $11(1)$ $1-24$ jan-abr 2021

menos favorecidos, tirando-lhes de um destino de marginalização para um outro de equidade social. É perceptível, também, que o oferecimento do Projeto se configura como uma preocupação da universidade em dar uma devolutiva à população, dirimindo as barreiras para o seu ingresso pelas comunidades mais pobres e silenciadas.

Nesse sentido, além do que foi mencionado anteriormente, o pré-vestibular conforma-se como um ato de resistência política e ideológica. Isso porque, embora a universidade pública, nos últimos anos, tenha sido alvo de sucateamento e de recessões financeiras, ela ainda financia oportunidades para que a educação passe a ser direito, e não privilégio de uma elite aristocrata.

A partir das aprovações nos vestibulares pelos alunos do UPT, devemos interpretar esse resultado de forma mais crítica e ampla no que se refere à participação global, já que essas ações não podem ser tidas como benefícios a um determinado grupo em detrimento de outros, mas, sim, como uma política pública imprescindível, visto que percebemos que a história da educação brasileira é marcada por um histórico de injustiças e direitos não asseverados.

\section{O ensino de Língua Portuguesa e os estudos do letramento}

Entre a década de 1960 e início da de 1970, as propostas de reformulação do ensino de língua materna indicavam, exclusivamente, transformações no modo de ensinar, desconsiderando os conteúdos de ensino. Acreditava-se que a valorização da criatividade do aluno seria o suficiente para o desenvolvimento de sua capacidade de comunicação e expressão. Além disso, tais propostas só contemplavam os segmentos médios da sociedade, sem se preocuparem com as consequências dessa prática nas camadas pobres (BRASIL, 1998).

O ensino de Língua Portuguesa pautado na tradição gramatical parecia, a princípio, adequado, porquanto os alunos que frequentavam a escola falavam uma variedade linguística bem próxima à chamada variedade padrão e traziam representações de mundo e língua semelhantes às que ofereciam os livros didáticos.

A partir da década de 1980, ancoradas no avanço das pesquisas nas áreas de Educação, Sociolinguística e Psicolinguística, muitas críticas foram feitas a tal modelo preconizado pela tradição normativa e por filólogos, principalmente, no que respeita à aquisição do código escrito. As críticas também estavam relacionadas à (1) desconsideração 
da realidade e dos interesses do alunado; (2) ao uso do texto como pretexto para o ensino de aspectos gramaticais, (3) ao preconceito contra as formas de oralidade e variedades não padrão; (4) ao ensino descontextualizado da metalinguagem e, por fim, (5) a uma teoria gramatical inconsistente (BRASIL, 1998).

$\mathrm{Na}$ atual conjuntura, muito ainda se discute sobre o real papel da disciplina de Língua Portuguesa, sobretudo, no ensino médio, acerca dos objetivos de tal disciplina e o que se espera que o aluno saiba ao concluir a educação básica. Conforme os PCN (Parâmetros Curriculares Nacionais) de Língua Portuguesa, ao findar da etapa do Ensino médio, espera-se que o educando possa (a) prosseguir em níveis mais complexos de estudos; (b) inserir-se no mercado de trabalho com condições de avançar, com autonomia, no delineamento de seu aprimoramento profissional e (c) atuar, de forma ética e responsável, na sociedade, exercendo a sua cidadania plena nas diversas dimensões da prática social (BRASIL, 2006).

Sob esse prisma, em síntese, o Ensino Médio deve preparar o aluno para dar prosseguimento aos estudos, integrar-se ao mundo do trabalho e para o exercício cotidiano de sua cidadania, algo que a BNCC (Base Nacional Comum Curricular) também preconiza (BRASIL, 2018). O que se defende aqui, também, é que as relações linguísticas, as produções de textos e a sua compreensão relacionam-se, intimamente, com o espaço no qual o aluno está inserido, possibilitando, sobretudo, a sistematização da língua, vista como instrumento, com as demais áreas da formação, constituindo um aprendizado interdisciplinar. Assim,

\footnotetext{
Sabemos que a escola tem a função de promover condições para que os alunos reflitam sobre os conhecimentos construídos ao longo de seu processo de socialização e possam agir sobre (e com) eles, transformando-os, continuamente, nas suas ações, conforme as demandas trazidas pelos espaços sociais em que atuam. Assim, se considerarmos que o papel da disciplina Língua Portuguesa, é o de possibilitar, por procedimentos sistemáticos, o desenvolvimento das ações de produção de linguagem em diferentes situações de interação, abordagens interdisciplinares na prática da sala de aula são essenciais (BRASIL, 2006, p. 27).
}

Refletindo, neste momento, no viés da promoção dos diversos letramentos pela escola, é importante que se pense acerca da formação escolar e por que, para além das questões estruturais dos institutos, os egressos do ensino médio, em especial oriundos de escola pública, não conseguem atingir um nível desejável de leitura e escrita, as quais, 
V. 11 (1) $1-24$ jan-abr 2021

aqui, são entendidas como práticas sociais. É nesse cenário, portanto, que é imperativo discutir e ter um olhar acurado para os discentes de cursinhos e (re)pensar a prática docente nesses espaços pautados nos eventos e práticas letradas em que os alunos - categoria diversa, sobretudo na conjuntura de ensino e aprendizagem do lócus investigado - estão imersos.

Em primeiro lugar, é preciso entender o que életramento e como uma pedagogia baseada nessa concepção pode desenvolver um melhor aprendizado da língua(gem). Dito isso, o letramento, segundo Kleiman (2005, p. 19) "está relacionado com os usos da escrita em sociedade e com o impacto da língua escrita na vida moderna". Ainda, é importante aclarar que, nesse construto, a língua é entendida como prática social, ou seja, é concebida para além de questões meramente relacionadas ao código, à metalinguagem, à estrutura pela estrutura. Assim, letramento é "um conjunto de práticas sociais que usam a escrita, enquanto sistema simbólico e enquanto tecnologia, em contextos específicos, para fins específicos" (KLEIMAN, 1995, p. 19). Ademais, como as práticas sociais são variadas, significa dizer que os letramentos também o são, daí se usar o vocábulo no plural. Desse modo,

Torna-se, então, necessário contemplar os letramentos multiculturais ou multiletramentos, ou seja, aqueles que abarcam os da cultura escolar e os dominantes, bem como os da cultura local e popular e os da cultura de massa; os letramentos multissemióticos, ou seja, os que compreendem diversas linguagens e semioses, como a oral e a escrita, imagética, musical e, ainda, os letramentos críticos e protagonistas, ou seja, aqueles que abarcam o tratamento ético dos discursos produzidos em uma sociedade nas diversas mídias e culturas (BAPTISTA, 2010, p.121).

Os conceitos de eventos de letramento e práticas letradas também são algo que devemos aclarar aqui, posto que lidamos diretamente com seus significados neste trabalho, sobretudo o primeiro. Assim, os eventos de letramento envolvem atividades em que o letramento tem protagonismo na prática que, no caso, é de linguagem (STREET, 2000). Outrossim, também são contextos em que a interação social é mediada pela escrita/leitura, fazendo com que a comunicação se estabeleça enquanto prática social (KLEIMAN, 2005). Assim sendo, em suma, 
estão fazendo quando estão usando a escrita e a leitura. Essa noção oferece ao pesquisador (ou ao professor que analisa o cotidiano de sua sala de aula) um modelo analítico para descrever e caracterizar quando, onde e como as pessoas leem ou escrevem, conversam sobre um texto escrito ou interagem por meio da escrita (STREET; CASTANHEIRA, 2014, p. 1).

Já no que diz respeito às práticas letradas, estas estão relacionadas aos significados que os participantes atribuem à leitura e à escrita. Assim, tais significados são situados social, cultural e historicamente, uma vez que os letramentos não se dão num vácuo contextual e ideológico, de modo que essa perspectiva põe em discussão questões de neutralidade linguística, discursiva e pedagógica (BAPTISTA, 2010). Salientamos, no entanto, que, neste trabalho, utilizamos apenas o conceito de eventos de letramento, por ser o foco do estudo.

\section{Análise dos eventos de letramento}

Nesta parte do artigo, apresentamos os eventos de letramento em que os alunos-informantes estavam imersos à época da geração dos dados. É importante, ainda, mencionar que dividimos esta seção em três, que é o número de questionários usados. No primeiro questionário, conhecemos o perfil do discente; no segundo, os eventos de letramento e, por fim, no terceiro, evidenciamos o uso e contato que os discentes tinham com o hipertexto.

Questionário 1: perfil dos estudantes

É de suma importância que conheçamos o perfil do discente ao (re)pensar a prática pedagógica, sobretudo quando estamos tratando do ensino público, em especial, em nível de cursinho, já que, em geral, a diversidade dos educandos é maior em relação à faixa etária, nível de escolaridade etc. É imprescindível, também, delimitar o universo no qual este estudo está inserido no intuito de compreender, com maior clareza, seu grau de abrangência. O grupo de participantes foi composto por 31 (trinta e um) estudantes do cursinho pré-vestibular Universidade Para Todos (UPT), o qual acontecia em regime presencial e no turno noturno. As aulas ocorriam em duas escolas públicas, ambos situados no bairro de Cajazeiras² (IV e V, respectivamente).

${ }^{2} \mathrm{O}$ bairro de Cajazeiras foi o primeiro bairro planejado de Salvador (em 1985) e é classificado, geograficamente, como um dos maiores bairros da capital. Tendo mais de 670 mil habitantes, é considerado como o $2^{\circ}$ bairro com maior concentração de pessoas da etnia negra, perdendo 
V. 11 (1)

1-24 jan-abr 2021

Nesse início, na tentativa de traçar um perfil socioeconômico dos nossos participantes, o questionário contemplou perguntas referentes aos seguintes aspectos: gênero, estado civil, consideração étnica, empregabilidade, formação escolar, desenvolvimento de atividades fora da escola, grau de escolaridade dos pais e renda familiar. Tais indicadores foram basilares para o estabelecimento de possíveis relações entre o modelo socioeconômico dos participantes e a sua inserção ou exclusão em eventos de letramentos. Vejamos, a seguir, os gráficos 1, 2 e 3 para conhecermos um pouco mais acerca do perfil dos estudantes que colaboraram com este estudo.

Gráfico 1 - Sexo dos sujeitos do estudo

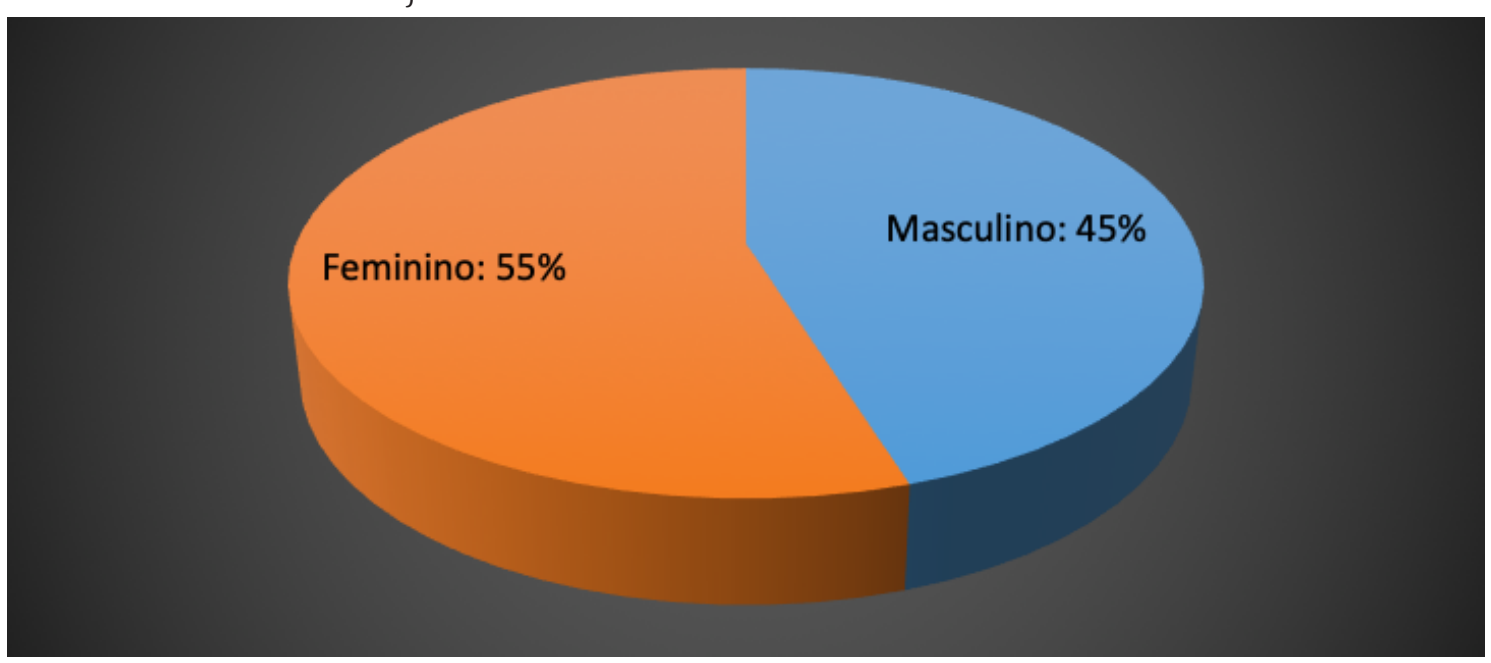

Fonte: autoria própria.

Gráfico 2 - Estado civil dos sujeitos do estudo

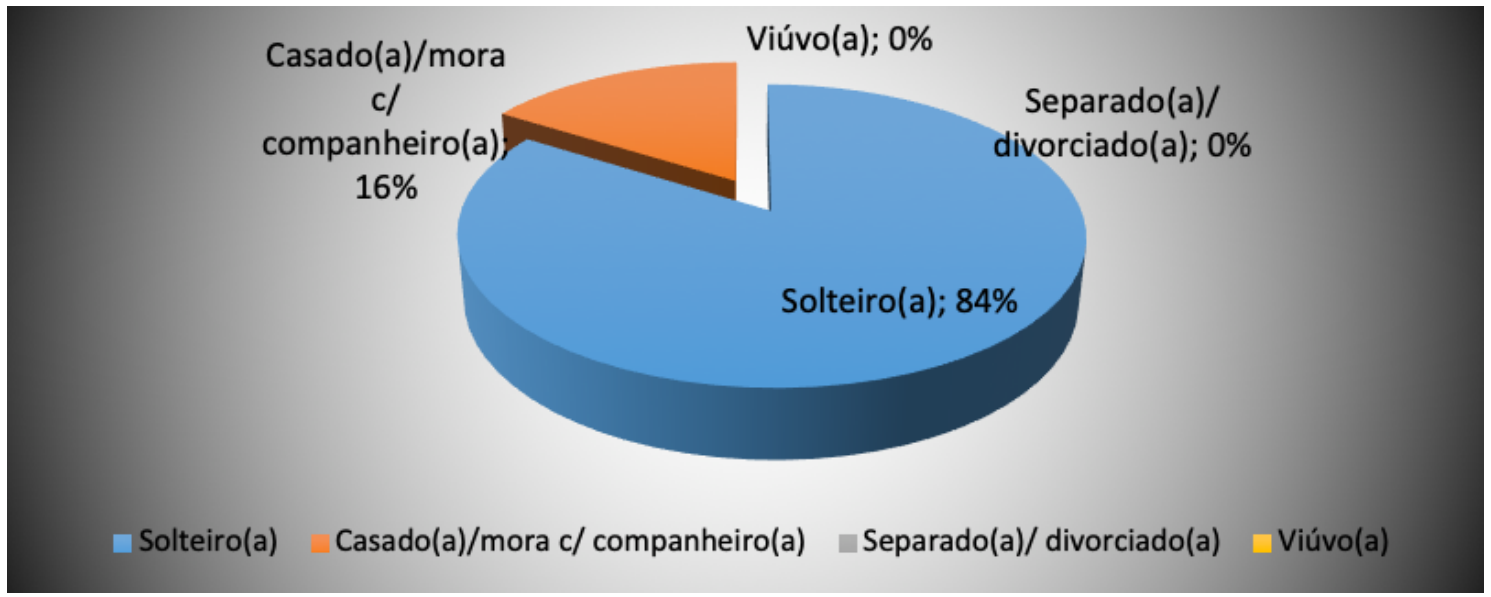

Fonte: autoria própria.

apenas para Pernambués. No que tange à sua organização, subdivide-se em: Cajazeiras 2, 3, 4, 5, 6, 7, 8, 10 e 11, Fazenda Grande 1, 2, 3 e 4, Águas Claras, Boca da Mata e Jaguaripe. 
Gráfico 3 - Consideração étnica

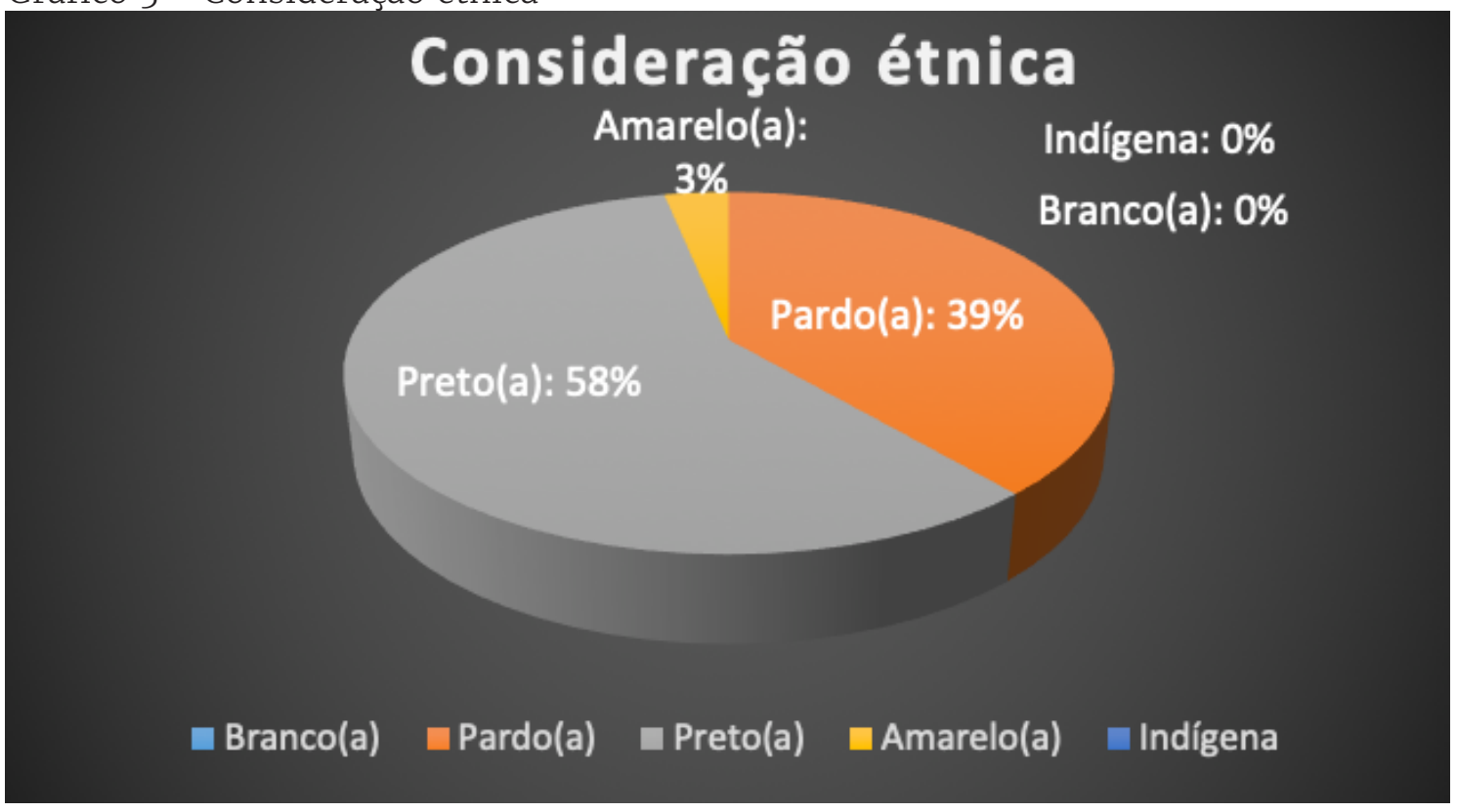

Fonte: autoria própria.

Com base nos gráficos anteriores, podemos afirmar que, quanto ao universo abarcado no que se refere ao gênero, o grupo divide-se em 55\% de homens e 45\% de mulheres, apresentando, assim, uma divisão quase igualitária nesse quesito. Vimos, também, que a maioria é solteiro(a). Temos 25 solteiros, 84\% dos participantes, e 6 casados/moram com o companheiro(a), 16\%. Ainda sobre o estado civil, verificamos que ninguém era viúvo ou separado/divorciado.

Quanto à sua consideração étnica, o grupo apresenta uma divisão diversificada, tendo, em sua maioria, 18 alunos pretos (58\%), 12 pardos (39\%), 1 amarelo (3\%) e nenhum se autodeclarando indígena ou branco. Tal dado pode ter sido decorrente de que, como o bairro é considerado o $2^{\circ}$ colocado em Salvador no que se refere à concentração de negros, o curso abrangeria um número maior desse segmento em detrimento dos demais. 
V. 11 (1)

$1-24$ jan-abr 2021

Gráfico 4 - Trabalho

\section{Trabalho}

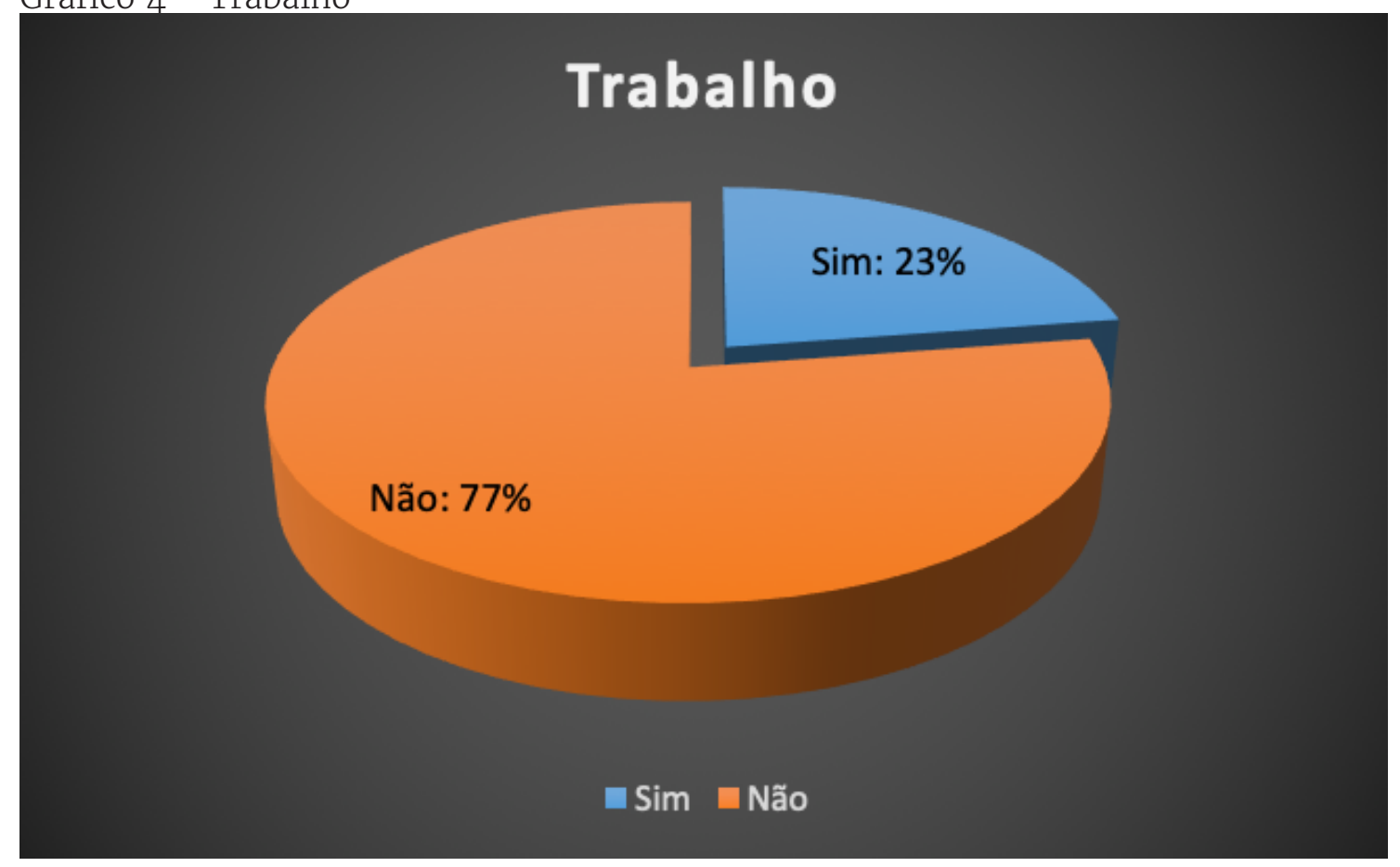

Fonte: autoria própria.

Gráfico 5 - Formação escolar

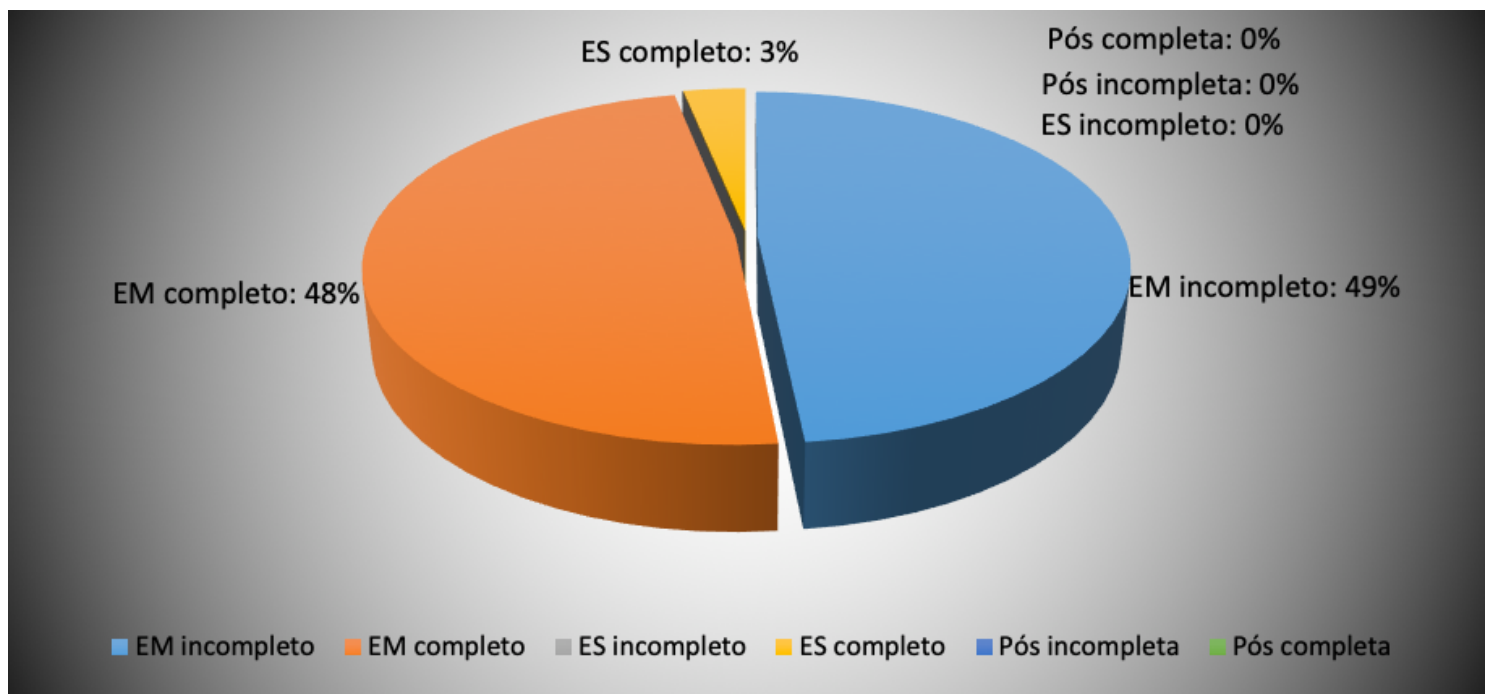

Fonte: autoria própria. 
Gráfico 6 - Atividades que desenvolve fora da escola

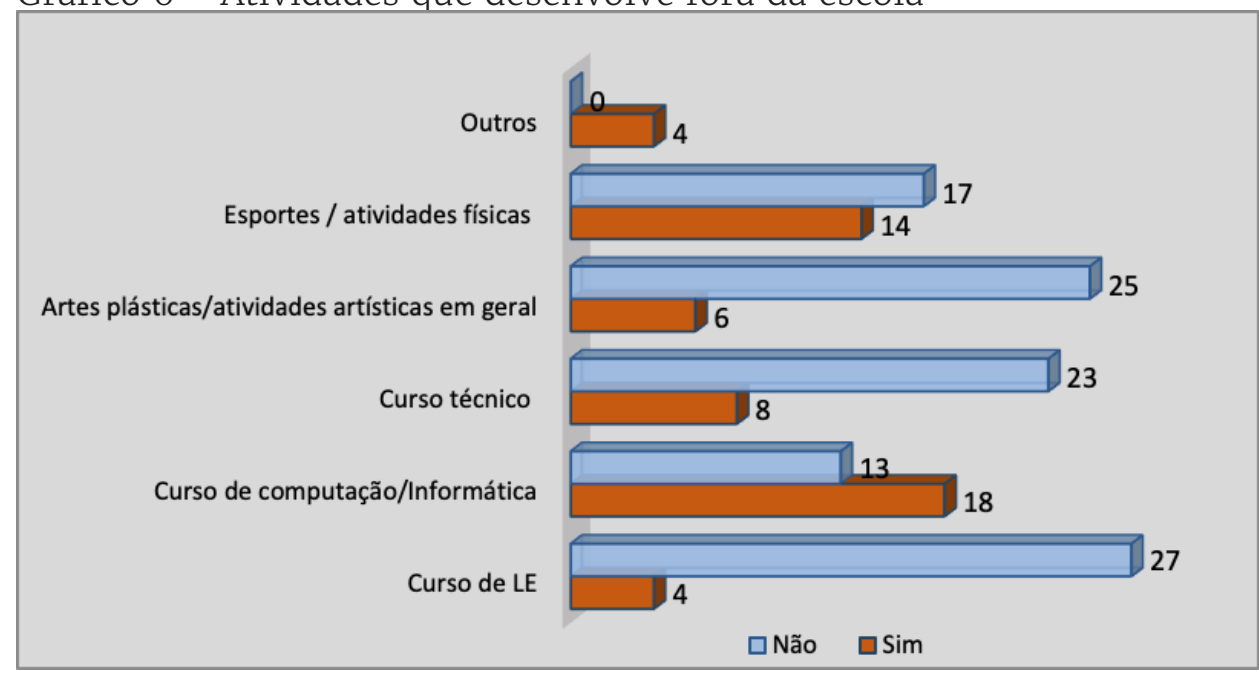

Fonte: autoria própria.

Ao analisarmos os gráficos 4, 5 e 6, conseguimos perceber algumas particularidades acerca da rotina diária desse alunado. Nesse sentido, no tocante ao número de alunos que trabalham, verificamos que a maioria dos estudantes não trabalham, perfazendo um total de $77 \%$, enquanto, apenas, $23 \%$ exercem alguma atividade remunerada, no contraturno, para ajudar nas despesas da casa.

Outro aspecto que nos chamou atenção no estudo foi a formação escolar desse público, a qual apresentou resultados equilibrados em duas categorias. De acordo com o gráfico, 49\% dos estudantes não tinham terminado o ensino médio, ou seja, estavam cursando o último ano da educação básica ( $3^{\circ}$ ano), $48 \%$ já tinham completado o ensino médio na rede pública e, apenas, 3\% afirmaram ter o ensino superior completo. Não houve alunos que se encaixassem nas outras categorias, como ensino superior incompleto, pós-graduação incompleta e pósgraduação completa. Esses dados nos levaram a pensar acerca da imprescindibilidade do pré-vestibular para o ingresso nas universidades, isso porque a maioria dos participantes estava cursando o $3^{\circ}$ ano $\mathrm{e}$ já pleiteavam ingressar no ensino superior, o que supomos ser fruto das novas exigências do mercado, bem como da noção de ampliação e universalização desses espaços para todas as camadas populares.

Outro quesito importante que foi analisado consistia em saber se os participantes exerciam alguma atividade formativa fora do ambiente escolar. Ao fazermos isso, estamos nos debruçando acerca das possiblidades de formação, além do espaço formal escolar. Tais atividades vão desde ações em áreas culturais até atividades físicas, as quais consideramos elementares para o desenvolvimento do sujeito. 
V. 11 (1) 1-24 jan-abr 2021

Dessa forma, ao analisarmos os cursos que os estudantes realizavam fora da escola, constatamos que 4 (12\%) afirmaram que iam para cursos de língua estrangeira, enquanto 27 (88\%) não. No que se refere aos cursos de computação/informática, 18 (58\%) faziam e 13 (42\%) não. Quando tentamos identificar a participação dos estudantes em cursos técnicos, vimos que $23(74 \%)$ deles não realizavam e apenas $8(26 \%)$ sim. No tocante à prática de atividades com artes plásticas e em geral, percebemos que apenas $6(19,4 \%)$ participavam, contra 25 $(80,6 \%)$ que não. Quanto à participação em atividades esportistas, 17 $(54,8 \%)$ afirmaram não ter contato e $14(45,2 \%)$ tinham. E, por fim, no que se refere a essa categoria de atividades fora da escola, apenas 4 $(12,9 \%)$ encaixaram-se no grupo Outros.

Gráfico 7 - Grau de escolaridade da mãe

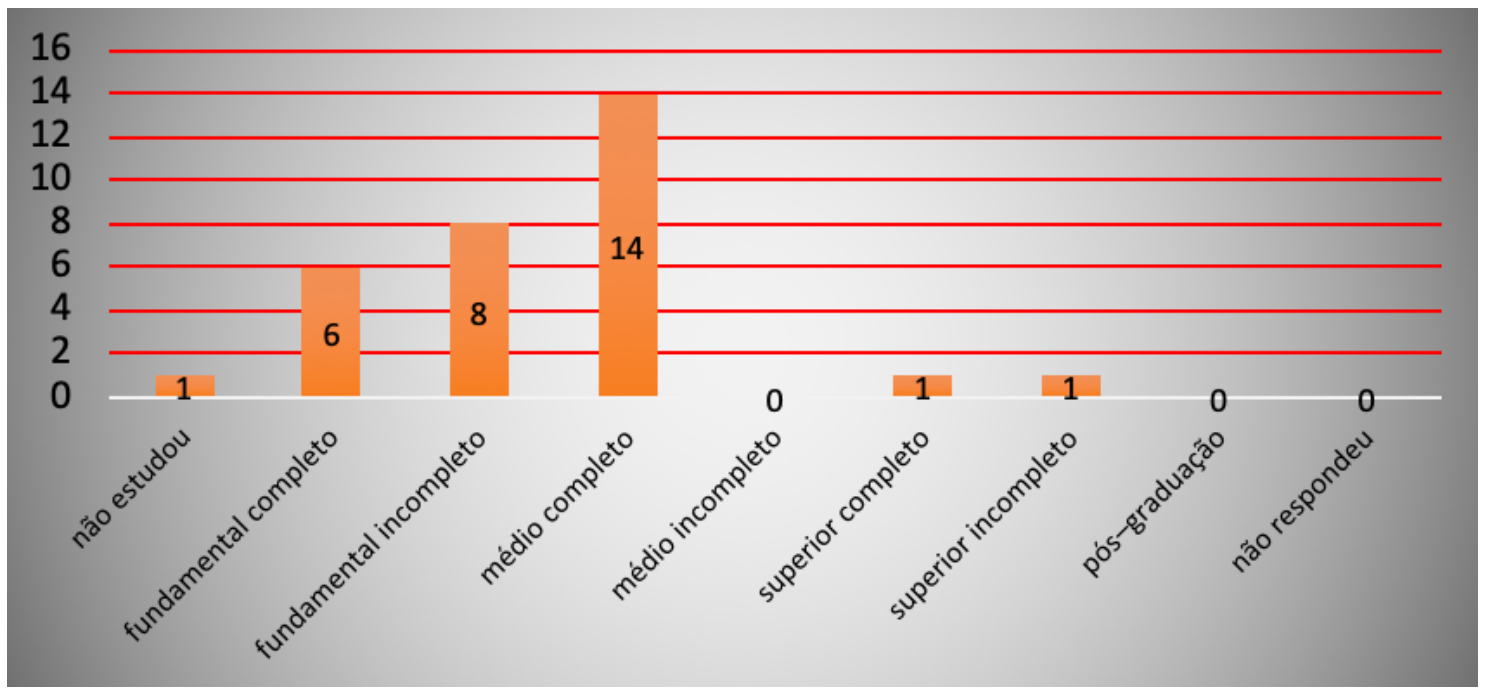

Fonte: autoria própria.

Gráfico 8 - Grau de escolaridade dos pais

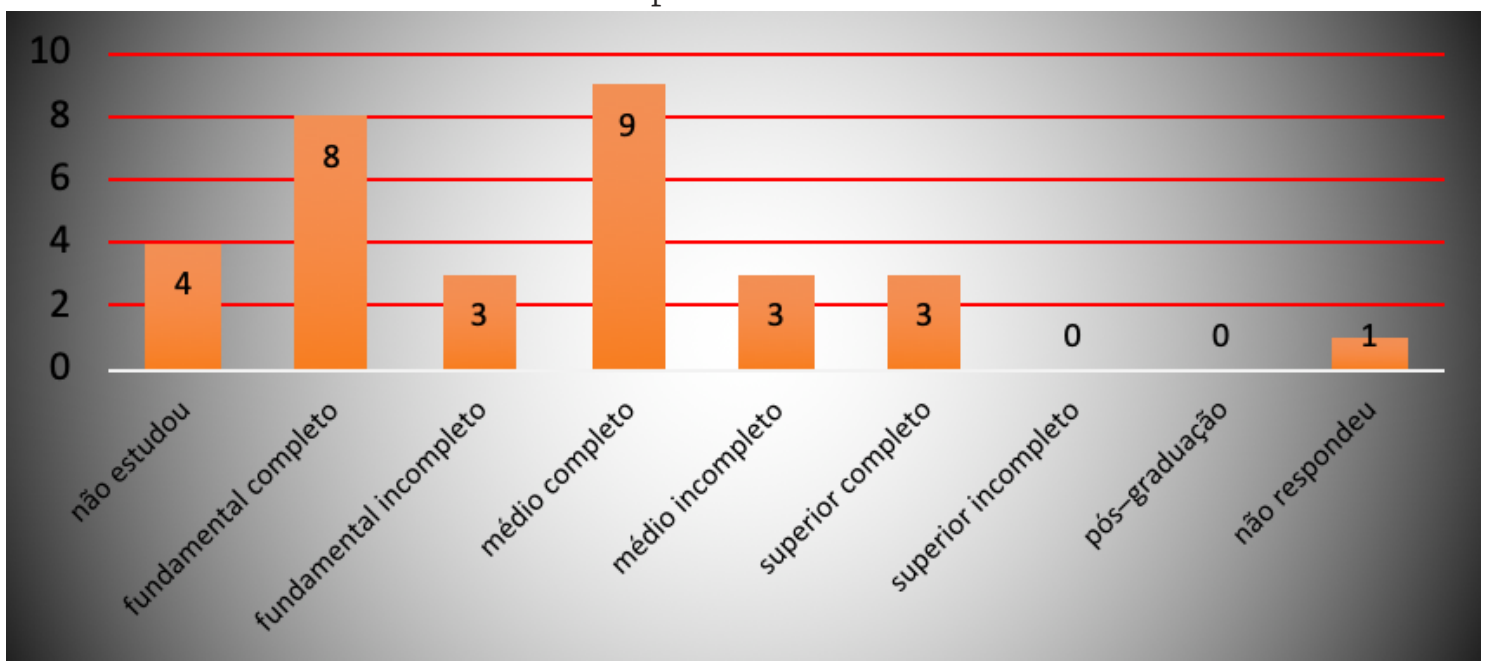

Fonte: autoria própria. 
Gráfico 9 - Renda familiar

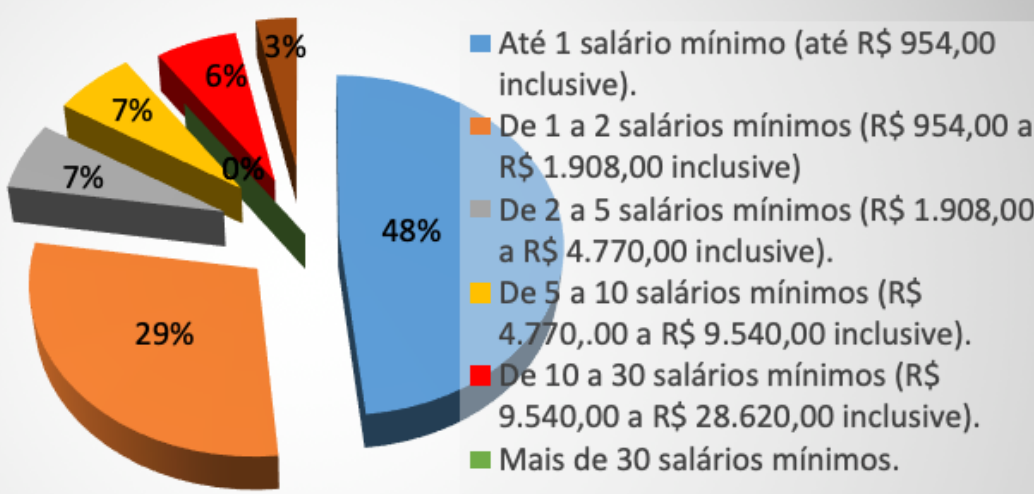

Fonte: autoria própria.

Consideramos relevante, também, compreender o processo de formação escolar dos familiares desses participantes. Nessa perspectiva, partimos da ideia de que a família influencia, sobremodo, a relação que esse participante estabelece com os eventos e práticas letradas. Embora não seja determinante, a partir desse dado, podemos fazer algumas suposições acerca da inserção/exclusão em certos eventos de letramento.

Para compor os dados relacionados à escolarização, tomamos como base de análise os níveis de escolarização do pai e da mãe. Em relação à mãe, constatamos que $1(3,2 \%)$ não estudou, 6 (19,35\%) delas têm fundamental completo, 8 (25,8\%) fundamental completo, 14 $(45,1 \%)$ ensino médio completo, $1(3,2 \%)$ superior completo, $1(3,2 \%)$ superior incompleto e, por fim, não tivemos declarações referentes ao ensino médio incompleto, à pós-graduação e de ninguém não ter respondido. Já referente à escolarização do pai, tivemos $4(12,9 \%)$ que não estudaram, 8 (25,8\%) com fundamental completo, 3 (9,6\%) com fundamental incompleto, 9 (29\%) com ensino médio completo, $3(9,6 \%)$ com ensino médio incompleto, 3 (9,6\%) com superior completo, $1(3,2 \%)$ não respondeu, além disso nenhum deles relatou o pai ter ensino superior incompleto ou pós-graduação. Quanto a esses dados, foi interessante perceber que a maioria tinha a escolarização no segmento do ensino médio e nenhum dos dados mostrou a presença da pós-graduação na formação dos pais, sendo que o cursinho UPT, a princípio, tem em seu objetivo macro o ingresso na universidade.

Por último, no que se refere à caracterização do perfil desses dados pessoais dos estudantes, analisamos o perfil de renda familiar deles e percebemos que $48 \%$ declaram ter renda de até 1 salário 
V. $11(1)$

$1-24$

jan-abr

2021

mínimo, 29\% possuem renda de 1 a 2 salários, $7 \%$ com renda de 2 a 5 salários, $7 \%$ de 5 a 10 salários, $6 \% 10$ a 30 salários, 3\% afirmaram não ter renda, sendo que nenhum afirmou ter uma renda superior a 30 salários mínimos. É importante salientar que nosso estudo não tinha como foco relacionar a renda diretamente com o letramento. Contudo, acreditamos que a renda familiar, juntamente com os outros aspectos analisados, pode influenciar os participantes na sua inserção/exclusão em eventos de letramento.

Questionário 2: eventos de letramento

Nesta subseção, analisamos, especificamente, os eventos de letramento em que os alunos informantes estão imersos, sobretudo em relação à experiência como leitor e os tipos e frequência de materiais de leitura. Vejamos, a seguir, o gráfico 10, primeiramente.

Gráfico 10 - Experiência de leitor no momento

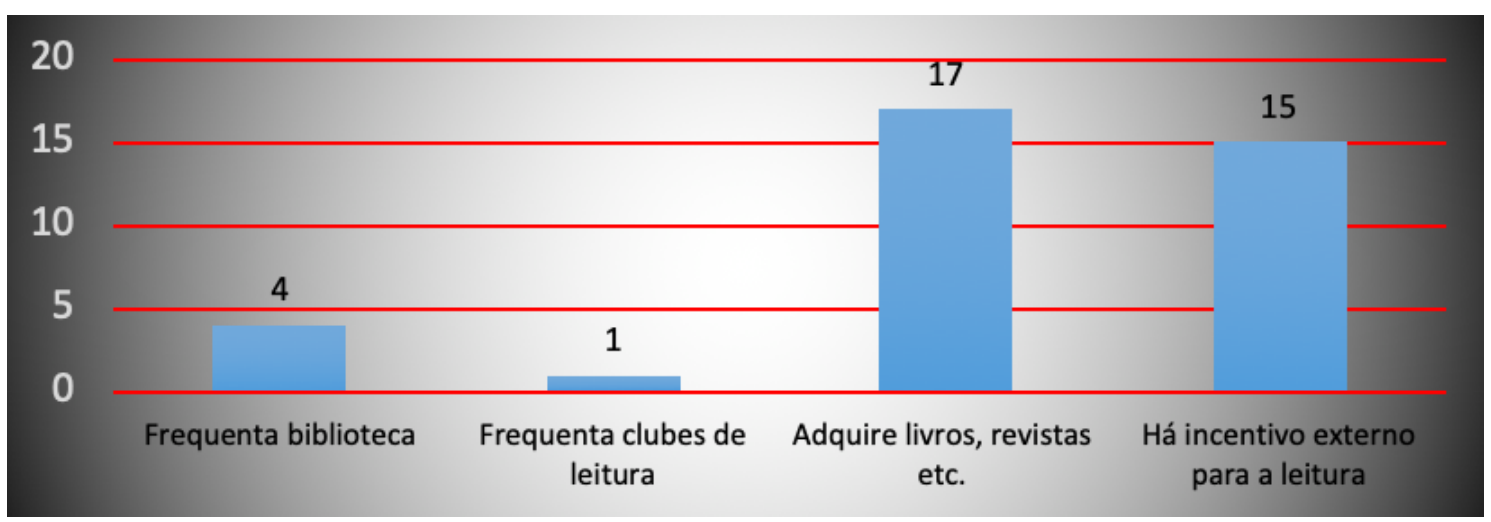

Fonte: autoria própria.

Quanto à aquisição de livros e revistas, 56\% (17) dos entrevistados responderam positivamente que o fazem. É importante saber desse dado para que se conheça que o público que vive na periferia tem acesso a esse tipo de material, contrariando o discurso do senso comum de que essas pessoas não adquirem materiais impressos de deleite e informação.

Já quanto a frequentar clubes de leitura, apenas 3,3\% (1) dos entrevistados responderam que sim; isso, por si, é sintomático em relação a essa prática dentro do entorno social em que estão inseridos, no qual, pelo que conhecemos, não há esse tipo de atividade. No entanto, $13 \%$ (4) disseram que frequentam bibliotecas. Estes estabelecimentos, ao contrário dos clubes de leitura, são comuns no bairro de onde são oriundos os alunos, o qual é grande; mesmo assim, o número de frequentadores é baixo. 
Quanto ao incentivo externo à leitura, 50\% dos informantes responderam de forma positiva. Muitos sinalizaram que os pais, em especial a mãe, incentivaram verbalmente ou possibilitou a ajuda financeira necessária para a compra de materiais. Outros, disseram que amigos, primos e a família em geral instigam à leitura. Entre os alunos mais velhos, os filhos tinham o papel de estimular a leitura. Nesse âmbito, por um lado, é importante notar o papel dos que estão mais próximos de impulsionar - além do professor, a escola - o acesso e promoção da leitura. Por outro lado, 50\% responderam que não possuem incentivos à leitura externo à instituição em que estudam, fato que é complicador na promoção dos letramentos. Levantando hipóteses, isso pode se dar, em geral, porque os que estão ao redor do sujeito provavelmente não possuem essa prática, logo também não o impulsionam a tal atividade.

Gráfico 11 - Frequência e tipo de material de leitura

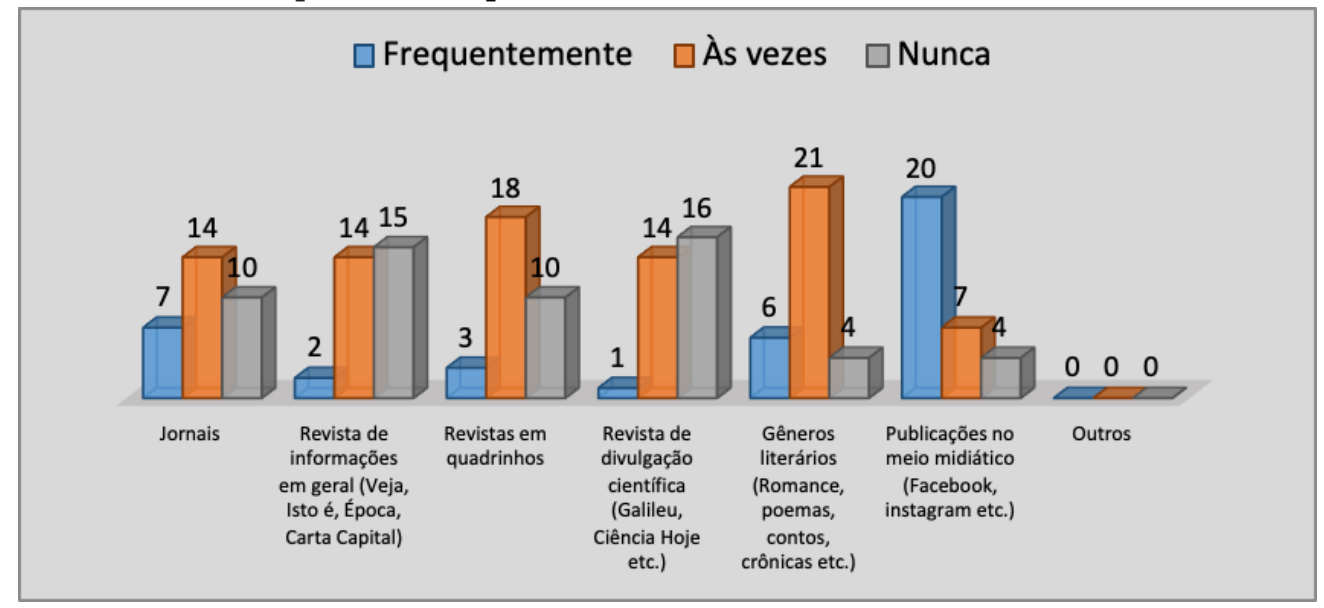

Fonte: autoria própria.

Passando, nesse momento, para a frequência e tipo de material de leitura (gráfico 11), a maioria dos alunos (64\%) respondeu que leem frequentemente publicações nas redes midiáticas, tais como as redes sociais digitais. Isso evidencia que os alunos possuem contato direto e constante com esse meio, fato que pode ser usado, entre outros aspectos, para que o professor possa trabalhar, por exemplo, os vários eventos e práticas letradas no meio digital. No entanto, os jornais (22\%), revistas informativas $(6,4 \%)$, de divulgação científica (3,2\%) e quadrinhos ( $9,6 \%)$ foram apontados por um baixo número de discentes como material que leem com frequência. Quanto aos materiais informativos impressos, esse baixo número pode se dar pelo fato de o referido material também ser divulgado em meio digital e, em geral, gratuito. Já no que diz respeito ao gênero quadrinho, em geral, o público de leitura desse material é 
V. 11 (1) 1-24 jan-abr 2021

mais restrito, daí o baixo número e, ainda, como já mencionado, a falta de incentivo externo - e interno à instituição - de ler diversos gêneros discursivos. Já os gêneros literários foram apontados por 19\% como textos que leem frequentemente, leitura, em geral, fomentada dentro da escola, a agência de letramentos por excelência.

Quanto, ainda, aos gêneros literários, o índice de frequência "às vezes" foi o maior, 67\%, e 12\% nunca leem. Em seguida, os jornais, as revistas de divulgação científica e informativa obtiveram o mesmo índice, 45\% de alunos que leem "às vezes". Quanto ao índice "nunca", assim configura-se a leitura dos outros materiais: jornais (32\%), revistas informativas (48\%), quadrinho (32\%), revista de divulgação científica (51\%). As altas cifras em relação a "nunca" ler alguns materiais importantes é algo que o docente deve ter atenção, porque é um indicativo característico de pouco acesso ou gosto para aquele tipo de texto, por motivos vários, e, em sala de aula, o professor pode fomentar a discussão sobre tal problemática.

\section{Questionário 3: Contato com o hipertexto}

Outro aspecto investigado, como já mencionado, diz respeito ao contato com o hipertexto e sua frequência de uso, uma vez que tínhamos o pressuposto de que o contato com o texto em ambiente digital era frequente, o que se revelou já no questionário 2, quando constatamos que há uma alta frequência de uso de redes sociais digitais, e nestas, como se sabe, circulam diversos gêneros.

Gráfico 12 - Contato com hipertexto e frequência de uso

\begin{tabular}{|c|}
\hline $\begin{array}{l}\text { \#tu a } \infty \text { mo dono, mediador/moderado r em alguma } \\
\text { comu nidade ness e site de } r \text { d adi onamento }\end{array}$ \\
\hline - Pos sui e-mailpessoal \\
\hline $\begin{array}{l}\text { Particip a de algum gupo de dis cus são tipo (Nahoo } \\
\text { grupos/grupos do facebook) }\end{array}$ \\
\hline = Particip a de alguma sala de bate papo \\
\hline - Pos sui site pess oal \\
\hline —Pos sui blog \\
\hline $\begin{array}{l}\text { - Pos sui Tinder , B adoo o u outro apli cativo de } \\
\text { relacion amento }\end{array}$ \\
\hline I Pos sui $\infty$ nta no Twitter \\
\hline $\begin{array}{l}\text { - Cos tuma fazer d ownl oads d e li vos s, dicion ár ios e/ou } \\
\text { outro smateriais p ara œon sulta. }\end{array}$ \\
\hline $\begin{array}{l}\text { Cos tuma fazer pesqui sas d e trabalho su tili zando } \\
\text { bus cadores da internet. }\end{array}$ \\
\hline $\begin{array}{l}\text { - Tem fad lid ad e para ler e compreender os texto sque } \\
\text { circulam nos divers os ambientes men cio nados }\end{array}$ \\
\hline
\end{tabular}

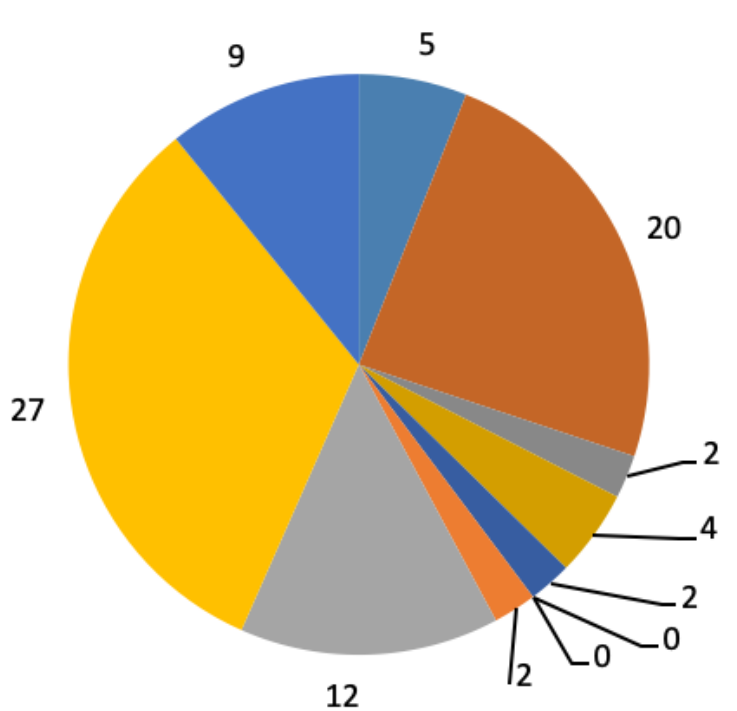

Fonte: autoria própria. 
De modo geral, no gráfico 12, observa-se que muitos hipertextos não são acessados por parte dos alunos, a exemplo de: Twitter, blogs, site pessoal e aplicativos de relacionamento. Portanto, ainda que muitos tenham acesso às redes sociais, como já observado, alguns disseram que frequentemente $(6,4 \%)$ e outros às vezes (25\%) participam de grupos de discussão nesse ambiente. Ademais, nesse âmbito, poucos $(16 \%)$ atuam como dono/mediador de alguma comunidade/grupo em redes sociais digitais.

Por outro lado, a maioria ( $87 \%$ ) respondeu que frequentemente fazem pesquisa de trabalho usando os buscadores da internet e, ainda, $38 \%$ costumam fazer download de livros, dicionários e materiais para consulta. A Internet funciona como uma enciclopédia, em geral, aberta, gratuita, de rápido acesso e resposta, daí um alto índice de alunos responderem que usam essa ferramenta em seus trabalhos, em geral escolares, de estudo.

Um último ponto para o qual devemos ter atenção é o dado referente à facilidade para ler os textos digitais: a maioria (64\%) respondeu que às vezes tem facilidade, outros (29\%) responderam que frequentemente têm facilidade e $7 \%$ asseveraram que não, ou seja, os textos do ambiente digital não são fáceis de ler. Tal aspecto deve ser tomado para análise de forma profunda, o que, pelo escopo deste artigo, é impossível de realizar. No entanto, alguns pontos podem ser problematizados, tais como: o que leva o aluno a dizer que o hipertexto é complicado de se ler? Que textos são mais simples, mais complexos no processo de leitura? Por que, às vezes, os discentes têm facilidade com algumas leituras e com outras não? Esses são alguns pontos problematizáveis.

\section{Considerações finais}

Neste estudo, observamos o quão importante é que a escola conheça os eventos de letramentos (e as práticas) nos quais os estudantes estão imersos. Isso, igualmente, não seria diferente no âmbito do cursinho pré-vestibular, o qual, na Bahia, é uma política pública importante de acesso à universidade, sobretudo por cidadãos dos estratos populares mais carentes dos mais diversos serviços públicos.

Os dados deste estudo mostram que a maioria dos alunos do projeto UPT, nas duas escolas investigadas, são solteiros, consideramse pretos e não trabalham. Já quanto à formação escolar, quase a metade 
V. $11(1)$ $1-24$ jan-abr 2021

dos educandos têm ensino médio completo e a outra, incompleto. Quanto às atividades fora da escola, salta aos olhos a problemática de que, na maioria das vezes, o índice de atividades é baixo: pouquíssimos alunos fazem curso de língua estrangeira, artes plásticas, cursos técnicos.

Levar em consideração o perfil do estudante, assim, é muito importante à hora de pensar o planejamento do ensino de língua, no nosso caso a materna. Isso implica considerar e trabalhar temas oriundos do cotidiano do estudante, asseverando e fomentando uma educação linguística libertadora, nos parâmetros e dizeres de Paulo Freire. Obviamente, tal prática deve ter em conta todos os tipos de letramentos, mas partir dos conhecimentos, eventos e práticas letradas dos discentes é algo essencial se se deseja uma educação linguística pautada na ética e na democrática de saberes.

Quanto às experiências de leitor, a maioria dos alunos adquire livros e revistas, mas os dados também mostram que a maior frequência de leitura está no ambiente digital, em especial nas redes sociais nesse ambiente. Em relação ao hipertexto, a maior frequência de uso é sites de busca, no âmbito de pesquisas gerais.

Os dados relacionados ao hipertexto não é algo estranho da realidade que já observamos numa sociedade dita "hipermidiatizada". O professor, por seu turno, não pode menosprezar tal questão, quando, no caso em análise, a maior frequência de leitura é no ambiente digital. Ter ciência do tipo e contato que os educandos têm com o hipertexto é essencial para promover aulas voltadas para os gêneros que circulam nesse espaço, de modo que o docente precisa promover o acesso à multiplicidade de textos que os discentes estão em frequente contato.

Neste texto, por questões de foco, não abordamos as práticas letradas, porém ressaltamos que também é interessante conhecê-las para ajudar no processo de ensino e aprendizagem de língua(gem), em especial a materna. Sendo assim, os problemas relacionados ao ensino de língua na escola pública são muitos e complexos, de modo que alternativas são criadas, pelo governo, para suprir alguns desses deficits, sobretudo os relacionados ao acesso dos alunos à universidade, como é o caso dos cursinhos e, em especial, do UPT, conforme já ressaltamos.

Nesse âmbito, conhecer os eventos de letramento dos educandos, dessa conjuntura educacional, foi nosso foco neste estudo, é primordial para que os professores possam (re)pensar o seu fazer profissional, bem como utilizar os conhecimentos que os educandos trazem à sala de aula como meio para ações de aprendizagens inovadoras 
e instigantes, não excluindo qualquer evento (e prática) de letramento (locais, globais, valorizados e não valorizados), o que corroborará para uma prática crítica e libertadora do ensinar e, por conseguinte, do aprender, uma vez que a formação educacional está para além da resolução de avaliações internas e externas.

\section{Referências}

BAPTISTA, L. M. T. R. Traçando caminhos: letramento, letramento crítico e ensino de espanhol. In: BARROS, C. S.; COSTA, E. G. M. Espanhol: ensino médio. Brasília: Ministério da Educação, Secretaria de Educação Básica, 2010. p.119- 136 .

BRASIL, Secretaria de Educação Básica. Linguagem, Códigos e suas Tecnologias. Volume 1. Brasília: Ministério da Educação/ Secretaria da Educação Básica, 2006. 239p.

BRASIL. Secretaria de Educação Fundamental. Parâmetros curriculares nacionais: terceiro e quarto ciclos do ensino fundamental: língua portuguesa. Brasília: Ministério da Educação/ Secretaria da Educação Básica, Brasília, 1998.

BRASIL. Constituição da República Federativa do Brasil. Brasília, DF: Senado Federal: Centro Gráfico, 1988.

BRASIL. Base Nacional Comum Curricular. Brasília: Ministério da Educação. Secretaria de Educação Básica. Brasília, 2018.

FREIRE, P. Pedagogia do Oprimido. Rio de Janeiro: Paz e Terra, 1987.

FURTADO, R. N. M. Letramentos e práticas letradas: impactos na formação do professor de espanhol em um polo de educação a distância no interior do Ceará. 2011. 191f. Dissertação (Mestrado em Linguística) - Universidade Federal do Ceará. Centro de Humanidades, Programa de Pós-Graduação em Linguística, Fortaleza-CE, 2011.

JORNAL EXTRACLASSE. Acesso à universidade é menor para alunos da rede pública. Disponível em: <https://www.extraclasse.org.br/ exclusivoweb/2018/12/acesso-a-universidade-e-menor-para-alunos-darede-publica/>. Acesso em: 18 de mar. de 2019.

KLEIMAN, A. B. Os significados do letramento: uma nova perspectiva sobre a prática social da escrita. Campinas: Mercado de Letras, 1995.

KLEIMAN, A. B. Preciso "ensinar" o letramento? Não basta ensinar a ler e escrever? Coleção Linguagem e Letramento em Foco, UNICAMP: Cefiel; MEC: Secretaria de Ensino Fundamental, 2005.

ORTEGA, E. M. V. O ensino médio público e o acesso ao ensino superior. Estudos em Avaliação Educacional. São Paulo, Fundação Carlos Chagas, n. 23, p. 153-176, jan./jun. 2004 .

SANTOS, M. C. E. M. Educação Superior, Políticas Públicas eContemporaneidade. XI Colóquio Internacional sobre Gestão Universitária na América do Sul e II 
V. 11 (1)

$1-24$

jan-abr 2021

Congresso Internacional IGLU. Anais do XI Colóquio Internacional sobre Gestão Universitária na América do Sul e II Congresso Internacional. Florianópolis, 2011.

STREET, B. CASTANHEIRA, M. L. Práticas e eventos de letramento. In: BREGUNCI, M. G. C. Glossário Ceale: termos de alfabetização, leitura e escrita para educadores. Belo Horizonte: UFMG/Faculdade de Educação, 2014.

STREET, B. Literacy events and literacy practices: theory and practice in the New Literacy Studies. In: JONES, M. M.; JONES, K. Multilingual Literacies: reading and writing different worlds. Amsterdam: John Benjamins, 2000.

WANDERLEY, S. F. Projeto Universidade Para Todos - UPT: uma Experiência de Inclusão e Formação Continuada. In: ANAIS DO IV CONEDU - CONGRESSO NACIONAL DE EDUCAÇÃO. Paraíba, 2017. 